\title{
An Outbreak of Babesiosis (B. divergens) in a Dairy Herd Comprising Different Age Groups of Cattle
}

Outbreaks of acute bovine babesiosis affecting several individuals within a herd are well known among veterinary practitioners and farmers within different parts of Sweden. Although outbreaks may not occur every year, they are feared by the farmers due to the unpredictability of the disease, its suddeness of onset, its rapid course, and the high mortality unless treated. Sporadic outbreaks of acute bovine babesiosis comprising several animals within a limited time period have been previously reported in Sweden (Linnaeus 1747, Bergman \& Waxberg 1915, Heijbel 1928), in Finland (Hinderson 1928), in Norway as cited by Tambs-Lyche (1943), in the United Kingdom (Donnelly et al. 1970) and elsewhere within the area where B. divergens is distributed (Tambs-Lyche 1943, Purnell 1980). In all of these cases groups of animals had been transferred onto pastures where clinical cases of bovine babesiosis were known to occur from areas where the disease was rare or had never occurred; i.e. unexposed animals were transferred onto pastures with Babesia infected ticks. The farmers first became aware of this situation after the outbreak had occurred.

The outbreak described here is interesting because it offers an opportunity to compare the morbidity of different age groups of naturally infected animals when exposed to the same infective source.

During the spring of 1981 a farmer had moved his herd of dairy animals from a part of an inland county (W) claimed to be free of babesiosis to an eastern county (D) from which clinical cases of babesiosis are commonly reported (Wahlgren et al. 1984). All of the animals moved from W to D county were born on the original farm in W county. Outbreaks of babesiosis had never occurred
Table 1. Number of infected animals (seropositive) and number of animals with symptoms of clinical babesiosis in the different age groups.

\begin{tabular}{rrrrrrrr}
\hline \multirow{2}{*}{$\begin{array}{l}\text { Age } \\
\text { years) }\end{array}$} & $\mathrm{n}$ & \multicolumn{2}{c}{ Infected } & & \multicolumn{2}{c}{ Clinical cases } \\
\cline { 3 - 4 } \cline { 6 - 7 } & & $\mathrm{n}$ & $\%$ & & $\mathrm{n}$ & \% of infected \\
\hline 3 & 16 & $11^{*}$ & 69 & & $9 *$ & 82 \\
2 & 3 & 3 & 100 & & 0 & \\
1 & 9 & 6 & 67 & & 1 & 17 \\
\hline & 28 & 20 & 71 & & 10 & 36 \\
\hline
\end{tabular}

* Including the two cows which died from acute babesiosis. They were undoubtedly infected although they were never tested serologically for Babesia.

on this farm. There were 16 cows 3 years or older, 3 heifers 2-2.5 years old, and 9 calves 11-19 months old. All of these cattle were let on one and the same pasture in D county. The former owner of that farm later informed the new owner that cases of acute babesiosis had occasionally occurred. Cattle had grazed on the pasture every year, including the preceding summer.

Within a period of 3 weeks in August 1981, 10 of the previously unexposed animals experienced acute babesiosis while on pasture (Table 1). Nine of them were cows and 1 was a 1 year old calf. Two of the cows died despite treatment with kinurid (Acaprin $\AA$ ). The symptoms noted were acute fever and haematuria. Because of a shortage of hay, the animals were kept on pasture until end of that autumn; but no more cases were seen.

All survivors were investigated serologically for antibodies ( $\mathrm{IgG})$ to Babesia divergens (Christensson 1987). Nine out of 16 cows all 3 heifers and 6 out of 9 calves - appeared to be seropositive. Despite the fact that roughly two-thirds of both calves and cows 
had been infected (Table 1), the clinical morbidity was apparently 5 times higher among the latter group, and the difference was statistically significant $(\mathrm{P}<0.05)$.

The result is in agreement with previous demonstration in Sweden of an inverse age resistance to naturally acquired clinical babesiosis (B. divergens) (Christensson \& Thorburn 1987) and with the results from own experimental infections with B. divergens of cattle of different age categories (Christensson \& Morén, to be published). The morbidity (any sign of clinical disease) of the cows was $69 \%$, which is more than 4 times more than Donnelly et al. (1972) described from a B. divergens infection in a herd in England. Inverse age resistance to natural infection with other Babesia species, e.g. B. bovis and B. bigemina, was first discussed by Smith \& Kilborne (1893), and has since been discussed by Callow \& Dalgliesh (1982), and others in relation to field observations in the United States, South America, and Australia.

\section{Dan A. Christensson and Erik Enfors,}

The Department of Veterinary Microbiology, Section of Parasitology, Swedish University of Agricultural Sciences and The National Veterinary Institute, Uppsala, and Distriktsveterinärstationen, Varberg, Sweden.

\section{References}

Bergman AM, Waxberg H: Om blodstallning, piroplasmos hos nötkreatur i Sverige. (About red water fever, Piroplasmosis in cattle in Sweden). Skandinavisk Veterinärtidskrift 1915, 5, 23-40.

Callow LL, Dalgliesh RJ: Immunity and immumunopathology in babesiosis. In: Immunology of Parasitic Infections, 2nd ed. (ed. Cohen S, Warren KS), Blackwell Scientific Publications 1982, 475-526.
Christensson DA: A modified IF-test to demonstrate IgM antibodies to Babesia divergens of cattle. Acta vet. scand. 1987, in press.

Christensson DA, Thorburn M: Age distribution of naturally occurring acute babesiosis in cattle in Sweden. Acta vet. scand. 1987, in press.

Donnelly J, Crossman PJ, McKendrick MD: An outbreak of redwater on a farm in Sussex. Vet. Rec. 1970, 87, 729-730.

Donnelly J, Joyner LP, Crossman PJ: The incidence of Babesia divergens infection in a herd of cattle as measured by the indirect immunofluorescent antibody test. Res. Vet. Sci. 1972, 13, 511-514.

Heijbel H: Piroplasmosen, behandling och skyddsympning. (The piroplasmosis, treatment and protective inoculation). III Nord. Vet. möte, 1928, p. 166-178.

Hinderson $R$ : Om skyddsympning mot och behandling av piroplasmos hos nötkreatur. (About protective inoculation of and treatment of bovine piroplasmosis). III Nord. Vet. möte, 1928, p. 192-209.

Linnaeus C: Västgöta Resa publ. i Uppsala 1747. (Travels in the county of Västergötland, publ. in Uppsala 1747). In: Carl Linnaei Västgötaresa (ed. Fries S, Edlund L-E) Wahlström \& Widstrand, Stockholm, 1978.

Purnell RE: Tick-borne disease as a barrier to efficient land use. Outlook on Agriculture 1980, 10, 230-234.

Smith $T$, Kilborne $F L$ : Investigations into the nature, causation and prevention of Texas or Southern Cattle Fever. U. S. Department of Agriculture, Bureau of Animal Industry. Bull. No. 1. 1893.

Tambs-Lyche $H$ : Ixodes ricinus og piroplasmosen i Norge. (Ixodes ricinus and the piroplasmosis in Norway). Norsk Veterinaertidskr. 1943, 55, 337-366, 401-441, 449-506, 513-542.

Wahlgren M, Christensson D, Bergquist R, Björkman, Pehrsson $P-O$, Rombo L: Babesios, en risksjukdom för immunodefekta i Sverige. (Babesiosis, a disease at risk for man with immunodeficiency diseases in Sweden). Opuscula Medica 1984, 29, 26-28.

(Received January 28, 1987).

Reprints may be requested from: D. Christensson, National Veterinary Institute, S-750 07 Uppsala.

Sweden. 